\title{
Down-regulated expression of SERPIN genes located on chromosome 18q21 in oral squamous cell carcinomas
}

\author{
MASASHI SHIIBA*, HITOMI NOMURA* , KEIJI SHINOZUKA, KENGO SAITO, YUKINAO KOUZU, \\ ATSUSHI KASAMATSU, YOSUKE SAKAMOTO, AKIYUKI MURANO, KANAE ONO, \\ KATSUNORI OGAWARA, KATSUHIRO UZAWA and HIDEKI TANZAWA

\begin{abstract}
Department of Clinical Molecular Biology, Graduate School of Medicine, Chiba University, 1-8-1 Inohana, Chuo-ku, Chiba city, Chiba 260-8670, Japan
\end{abstract}

Received March 8, 2010; Accepted April 21, 2010

DOI: $10.3892 /$ or_00000852

\begin{abstract}
Serpins (serine protease inhibitors) are known as a diverse family of protease inhibitors; however, various other biological activities including tumor suppression, have been recently reported for these molecules. To clarify whether members of the serpin family are involved in OSCC (oral squamous cell carcinoma), global gene screening using microarray analysis was performed with OSCC-derived cell lines. A trend toward diminished expression was shown for some SERPIN genes located on 11q12-q13.1 and 18q21. mRNA expression of SERPIN genes at these chromosome regions was therefore analyzed using real-time quantitative RT-PCR (qRT-PCR) in 55 OSCC samples and matched normal tissue. Statistically significant decreases in expression were found for SERPINB $12(\mathrm{P}=0.001)$, SERPINB $13 \quad(\mathrm{P}=0.001)$, SERPINB4 $(\mathrm{P}=0.042)$, SERPINB3 $(\mathrm{P}<0.001)$, SERPINB11 $(\mathrm{P}<0.001)$, SERPINB7 $(\mathrm{P}=0.021)$ and SERPINB2 $(\mathrm{P}=0.018)$. All of these genes are located on 18q21, the known location of the serpin gene cluster. The results strongly suggest that this chromosome region plays a crucial role in OSCC. Some serpin members in the region might be involved in tumor suppression, or there might be unidentified tumor suppressor genes within or near the chromosome region.
\end{abstract}

\section{Introduction}

Serpins (serine protease inhibitors) are the largest and most broadly distributed superfamily of proteins containing a conserved domain. Most serpins inhibit serine proteases; however, some inhibit caspases or papain-like cysteine

Correspondence to: Dr Masashi Shiiba, Department of Clinical Molecular Biology, Graduate School of Medicine, Chiba University, 1-8-1 Inohana, Chuo-ku, Chiba city, Chiba 260-8670, Japan

E-mail: m.shiiba@faculty.chiba-u.jp

*Contributed equally

Key words: serpin, oral squamous cell carcinoma, chromosome 18 proteases $(1,2)$. Several members of the group show noninhibitory activities, functioning as hormone transporters, molecular chaperones or tumor suppressors (3-6). SERPINB5 (maspin) was first identified as a tumor suppressor protein in human breast cancer, and the diminished expression of this protein has been frequently observed in advanced human breast cancer specimens (6). Correlations between SERPINB5 expression and clinical features have been previously reported; however, both up- and down-regulation have been observed in various tumors, and some investigators have noted its paradoxical expression (7-10). In oral carcinoma, Xia et al suggested that higher SERPINB5 expression was significantly associated with better overall survival (11). Furthermore, down-regulated expression of the SERPINB13 (headpin/ hurpin) gene has been demonstrated in head and neck malignancies (12-14). Both SERPINB5 and SERPINB13 genes are located on chromosome $18 \mathrm{q}$, which is the location of the serpin gene cluster and other members of serpin family. Frequent genetic alterations have been observed in this chromosomal region in head and neck malignancies (15-20). We previously reported that loss of heterozygosity ( $\mathrm{LOH})$ at $18 \mathrm{q} 21$ was observed in $43.8 \%$ of oral squamous cell carcinomas, and that this was significantly correlated with the clinicopathological features (21). These studies suggest that serpin family members located on chromosome $18 \mathrm{q}$ play crucial roles and might act as tumor suppressors in oral squamous cell carcinomas.

The aim of this study was to investigate expression profiles of serpin family members in OSCC and to clarify the relationship between their expression profiles and clinical features.

\section{Materials and methods}

Cell culture. The OSCC-derived cell lines used in this study were HSC2, HSC3 and CA9-22 (Human Science Research Resources Bank, Osaka, Japan); plus H1 and Sa3 (provided by Dr S. Fujita, Wakayama Medical University, Wakayama, Japan). All OSCC-derived cell lines were cultured in Dulbecco's modified Eagle medium/F-12 HAM (SigmaAldrich Co., St. Louis, MO, USA) supplied with $10 \%$ heatinactivated fetal bovine serum (Sigma-Aldrich) and $50 \mathrm{U} / \mathrm{ml}$ penicillin and streptomycin (Sigma-Aldrich). All cell lines were incubated at $37^{\circ} \mathrm{C}$ in a humidified atmosphere with $5 \%$ $\mathrm{CO}_{2}$. 
Table I. Clinicopathological features of oral squamous cell carcinoma cases examined in the study.

\begin{tabular}{|c|c|}
\hline Profiles of cases & No. \\
\hline \multicolumn{2}{|l|}{ Age (year old) } \\
\hline Range & $46-84$ \\
\hline Mean & 63.9 \\
\hline \multicolumn{2}{|l|}{ Gender } \\
\hline Male & 37 \\
\hline Female & 18 \\
\hline \multicolumn{2}{|l|}{ Differentiation } \\
\hline Well & 31 \\
\hline Moderately & 23 \\
\hline Poorly & 1 \\
\hline \multicolumn{2}{|l|}{ Tumor size $(\mathrm{T})$} \\
\hline $\mathrm{T} 1$ & 4 \\
\hline $\mathrm{T} 2$ & 23 \\
\hline $\mathrm{T} 3$ & 10 \\
\hline $\mathrm{T} 4$ & 18 \\
\hline \multicolumn{2}{|c|}{ Regional neck metastasis (N) } \\
\hline No & 17 \\
\hline N1 & 10 \\
\hline $\mathrm{N} 2 \mathrm{a}$ & 4 \\
\hline $\mathrm{N} 2 \mathrm{~b}$ & 16 \\
\hline $\mathrm{N} 2 \mathrm{c}$ & 8 \\
\hline \multicolumn{2}{|c|}{ Distant metastasis (M) } \\
\hline M0 & 55 \\
\hline M1 & 0 \\
\hline \multicolumn{2}{|c|}{ Stage classification } \\
\hline I & 4 \\
\hline II & 21 \\
\hline III & 0 \\
\hline IV & 30 \\
\hline
\end{tabular}

RNA extraction from OSCC-derived cell lines and OSCC samples. Total RNA was extracted from each cell line and tissue samples using TRIzol Reagent (Invitrogen Life Technologies, Carlsbad, CA, USA) according to the manufacturer's instructions. Each extracted RNA sample was stored separately at $-80^{\circ} \mathrm{C}$ until use.

DNA microarray analysis of OSCC-derived cell lines. Double-stranded cDNA was synthesized from $20 \mu \mathrm{g}$ of total RNA from each cell line and tissue samples using the Superscript Choice system (Invitrogen Life Technologies). A biotin-labeled in vitro transcription reaction was carried out using the cDNA template (Enzo Bioarray, Farmingdale, NY, USA). According to the manufacturer's protocols (Affymetrix, Santa Clara, CA, USA), $7 \mu \mathrm{g}$ of cRNA was fragmented and added to the hybridization mixture. Expression profiles were
Table II. Specific primer sequences used in real-time quantitative RT-PCR analysis.

\begin{tabular}{|c|c|}
\hline Target gene & Primer sequence \\
\hline \multicolumn{2}{|l|}{ SERPINB6 } \\
\hline$(\mathrm{F})$ & 5'-GGCACGCAGTACTTGCTTAGGA-3' \\
\hline$(\mathrm{R})$ & 5'-GCTACCCAGGTGTTTATGTG-3' \\
\hline \multicolumn{2}{|l|}{ SERPING1 } \\
\hline (F) & 5'-GCAAGGGACCTGCTTCTATTAGC-3' \\
\hline$(\mathrm{R})$ & 5'-AGAGAAAGCTGCAAAAAGTGGTTT-3' \\
\hline \multicolumn{2}{|l|}{ SERPINB5 } \\
\hline (F) & 5'-GTGGTTGGCACTAGACTGG-3' \\
\hline$(\mathrm{R})$ & 5'-CAAGGTAACGTGAGCACTTTAATC-3' \\
\hline \multicolumn{2}{|l|}{ SERPINB12 } \\
\hline (F) & 5'-GACAAGAGATTAACTTCTGG-3' \\
\hline$(\mathrm{R})$ & 5'-CTTGTTTTCATTCGCATTTA-3' \\
\hline \multicolumn{2}{|l|}{ SERPINB13 } \\
\hline (F) & 5'-GGCATAGGCTTTACTGTCACATCC-3' \\
\hline$(\mathrm{R})$ & 5'-CAAGACTGGAAATGCAAGTGAGAC-3' \\
\hline \multicolumn{2}{|l|}{ SERPINB4 } \\
\hline$(\mathrm{F})$ & 5'-GCCAAGGTCCTGGAAATACCA-3' \\
\hline$(\mathrm{R})$ & 5'-TTCCATCAATTTCTCAGCAGTGA-3' \\
\hline \multicolumn{2}{|l|}{ SERPINB3 } \\
\hline (F) & 5'-GGTTACAGAGGAGGGAGCAGAA-3' \\
\hline$(\mathrm{R})$ & 5'-GGGTGATTACAATGGAACTCTTCA-3' \\
\hline \multicolumn{2}{|l|}{ SERPINB 11} \\
\hline$(\mathrm{F})$ & 5'-TACCCTCAGCATTGCCAACA-3' \\
\hline$(\mathrm{R})$ & 5'-CAGTTTGCAACCTGGCTTGATA-3' \\
\hline \multicolumn{2}{|l|}{ SERPINB7 } \\
\hline$(\mathrm{F})$ & 5'-CACTGGTGACTTGACCCTTCCT-3' \\
\hline$(\mathrm{R})$ & 5'-GGTGAGACACATGGTGGTAGAATG-3' \\
\hline \multicolumn{2}{|l|}{ SERPINB2 } \\
\hline (F) & 5'-CAGATCCAGAAGGGTAGTTA-3' \\
\hline$(\mathrm{R})$ & 5'-CAGACTTCTCACCAAACAGCTT-3' \\
\hline \multicolumn{2}{|l|}{ SERPINBIO } \\
\hline (F) & 5'-AGCTGAATGAGTGGACCAG-3' \\
\hline$(\mathrm{R})$ & 5'-TCCTGAGAAATCAGCTTTGC-3' \\
\hline \multicolumn{2}{|l|}{ SERPINB8 } \\
\hline (F) & 5'-CGATCCCCTGACAAAGCTG-3' \\
\hline$(\mathrm{R})$ & 5'-TTAGCTTCCTTAAACATCAT-3' \\
\hline
\end{tabular}

created using the Human Genome U 133 Plus 2.0 arrays containing 54675 probe sets (Affymetrix). Arrays were stained with phycoerythrin-streptavidin antibody followed by a second staining with phycoerythrin-streptavidin and then scanned using Affymetrix Gene Chip Operating Software 1.1 (Affymetrix). 
Table III. Expressions of SERPIN genes determined with DNA microarray analysis.

Relative value (vs. human normal oral keratinocyte)

\begin{tabular}{|c|c|c|c|c|c|c|c|c|}
\hline \multirow[b]{2}{*}{ Symbol } & \multirow[b]{2}{*}{ Genbank } & \multirow[b]{2}{*}{ Chromosome location } & \multirow[b]{2}{*}{ Affymetrix no. } & & & & & \\
\hline & & & & H1 & $\mathrm{Sa} 3$ & $\mathrm{~KB}$ & HSC2 & HSC3 \\
\hline SERPINCI & ВC022309 & 1q23-q25.1 & 1554491_a_at & 5.33 & 1.25 & 0.87 & 3.61 & 3.49 \\
\hline SERPINE2 & AI359165 & $2 q 33-q 35$ & 227487_s_at & 1.15 & 0.20 & 0.10 & 1.13 & 0.23 \\
\hline SERPINII & NM_005025 & $3 q 26.1$ & 205352_at & 1.03 & 0.36 & 0.94 & 0.85 & 0.13 \\
\hline SERPINI2 & NM_006217 & $3 q 26.1-q 26.2$ & 207636_at & 0.79 & 0.11 & 0.29 & 0.48 & 0.59 \\
\hline SERPINBI & NM_030666 & $6 \mathrm{p} 25$ & 212268_at & 0.46 & 0.75 & 1.06 & 0.61 & 1.13 \\
\hline SERPINB9 & AI986192 & $6 \mathrm{p} 25$ & 242814_at & 0.39 & 0.63 & 0.10 & 0.13 & 0.37 \\
\hline SERPINB6 & AW275007 & $6 \mathrm{p} 25$ & 1556950_s_at & 0.67 & 0.65 & 0.90 & 0.46 & 0.89 \\
\hline SERPINE1 & ВC020765 & $7 q 21.3-q 22$ & 1568765_at & 0.73 & 1.26 & 0.36 & 3.01 & 1.96 \\
\hline SERPING1 & NM_000062 & 11q12-q13.1 & 200986_at & 0.06 & 0.26 & 0.07 & 0.09 & 0.10 \\
\hline SERPINHI & NM_004353 & $11 \mathrm{q} 13.5$ & 207714_s_at & 1.04 & 0.20 & 1.36 & 5.64 & 2.06 \\
\hline SERPINAIO & NM_016186 & $14 q 32.13$ & 220626_at & 1.05 & 0.65 & 0.41 & 0.62 & 0.51 \\
\hline SERPINA6 & NM_001756 & $14 q 32.13$ & 206325_at & 2.55 & 1.46 & 1.39 & 0.52 & 1.54 \\
\hline SERPINA2 & NM_006220 & $14 q 32.13$ & 208531_at & 0.38 & 0.39 & 0.16 & 0.61 & 0.34 \\
\hline SERPINAI & T62088 & $14 q 32.13$ & 230318_at & 2.36 & 0.80 & 1.36 & 0.45 & 2.67 \\
\hline SERPINAII & AY185496 & $14 q 32.13$ & 1553499_s_at & 1.84 & 2.04 & 1.40 & 1.59 & 1.86 \\
\hline SERPINA4 & NM_006215 & $14 q 32.13$ & 213874_at & 0.85 & 1.06 & 0.78 & 0.57 & 1.11 \\
\hline SERPINA3 & NM_001085 & $14 q 32.13$ & 202376_at & 0.47 & 8.93 & 0.79 & 3.09 & 0.28 \\
\hline SERPINF2 & NM_000934 & $17 p 13.1$ & 205075_at & 2.49 & 1.45 & 1.94 & 1.81 & 0.72 \\
\hline SERPINF1 & NM_002615 & $17 \mathrm{p} 13.1$ & 202283_at & 0.19 & 0.40 & 0.30 & 1.79 & 0.60 \\
\hline SERPINB5 & NM_002639 & $18 \mathrm{q} 21.3$ & 204855_at & 0.05 & 0.27 & 0.01 & 0.26 & 0.03 \\
\hline SERPINB12 & NM_080474 & $18 \mathrm{q} 21.3$ & 1553057_at & 6.44 & 3.00 & 4.89 & 0.31 & 4.50 \\
\hline SERPINB13 & AF169949 & $18 q 21.3-q 22$ & 211362_s_at & 0.35 & 0.15 & 0.20 & 0.36 & 0.61 \\
\hline SERPINB4 & U19557 & $18 \mathrm{q} 21.3$ & 210413_x_at & 0.39 & 0.57 & 0.44 & 1.26 & 1.02 \\
\hline SERPINB3 & U19556 & $18 \mathrm{q} 21.3$ & 209719_x_at & 0.29 & 0.43 & 0.22 & 0.99 & 0.59 \\
\hline SERPINBI1 & NM_080475 & $18 \mathrm{q} 21.3$ & 1552463_at & 0.73 & 0.38 & 0.67 & 0.76 & 0.88 \\
\hline SERPINB7 & NM_003784 & $18 q 21.33$ & 206421_s_at & 0.04 & $<0.01$ & $<0.01$ & 0.14 & 0.21 \\
\hline SERPINB2 & NM_002575 & $18 \mathrm{q} 21.3$ & 204614_at & $<0.01$ & $<0.01$ & $<0.01$ & 0.63 & 1.41 \\
\hline SERPINBI0 & NM_005024 & $18 \mathrm{q} 21.3$ & 214539_at & 0.16 & 0.34 & 0.54 & 0.62 & 1.28 \\
\hline SERPINB8 & NM_002640 & $18 \mathrm{q} 21.3$ & 206034_at & 0.23 & 0.05 & 0.26 & 0.36 & 0.36 \\
\hline SERPINDI & NM_000185 & $22 q 11.21$ & 205576_at & 8.84 & 2.75 & 0.66 & 13.10 & 2.01 \\
\hline SERPINA7 & NM_000354 & $\mathrm{Xq} 22.1$ & 206386_at & 1.06 & 1.47 & 1.16 & 0.15 & 1.41 \\
\hline
\end{tabular}

Values $<0.2$ are shown in bold.

Tissue samples. Fifty-five pairs of samples were obtained at the time of surgery performed at Chiba University Hospital between 1998 and 2006. The paired samples consisted of primary OSCC and normal oral epithelial tissue. All patients provided informed consent according to a protocol reviewed and approved by the institutional review board of Chiba University. Postoperative follow-up data were collected until April 2008 or until death, metastasis or local recurrence. Histopathologic diagnosis of each tumor specimen was performed by the Department of Pathology, Chiba University Hospital, according to the International Histological Classification of Tumors. All OSCC samples were histologically confirmed and checked to ensure the presence of tumor in $>80 \%$ of each specimen. Clinicopathological features of OSCC cases examined in the present study are shown in Table I.

mRNA expression analysis using real-time quantitative reverse transcriptase-polymerase chain reaction ( $q R T-P C R)$. Among a total of 31 genes, 11 SERPIN genes were selected by the expression profiles determined by DNA microarray analysis and were subjected to real-time qRT-PCR analysis. Before cDNA synthesis, residual genomic cDNA was removed from the total RNA using DNAse I treatment (DNA-free, Ambion, Austin, TX, USA). The nucleotide sequences of genespecific primers for qRT-PCR analysis are shown in Table II. Before use, the sequences of gene-specific primers were 


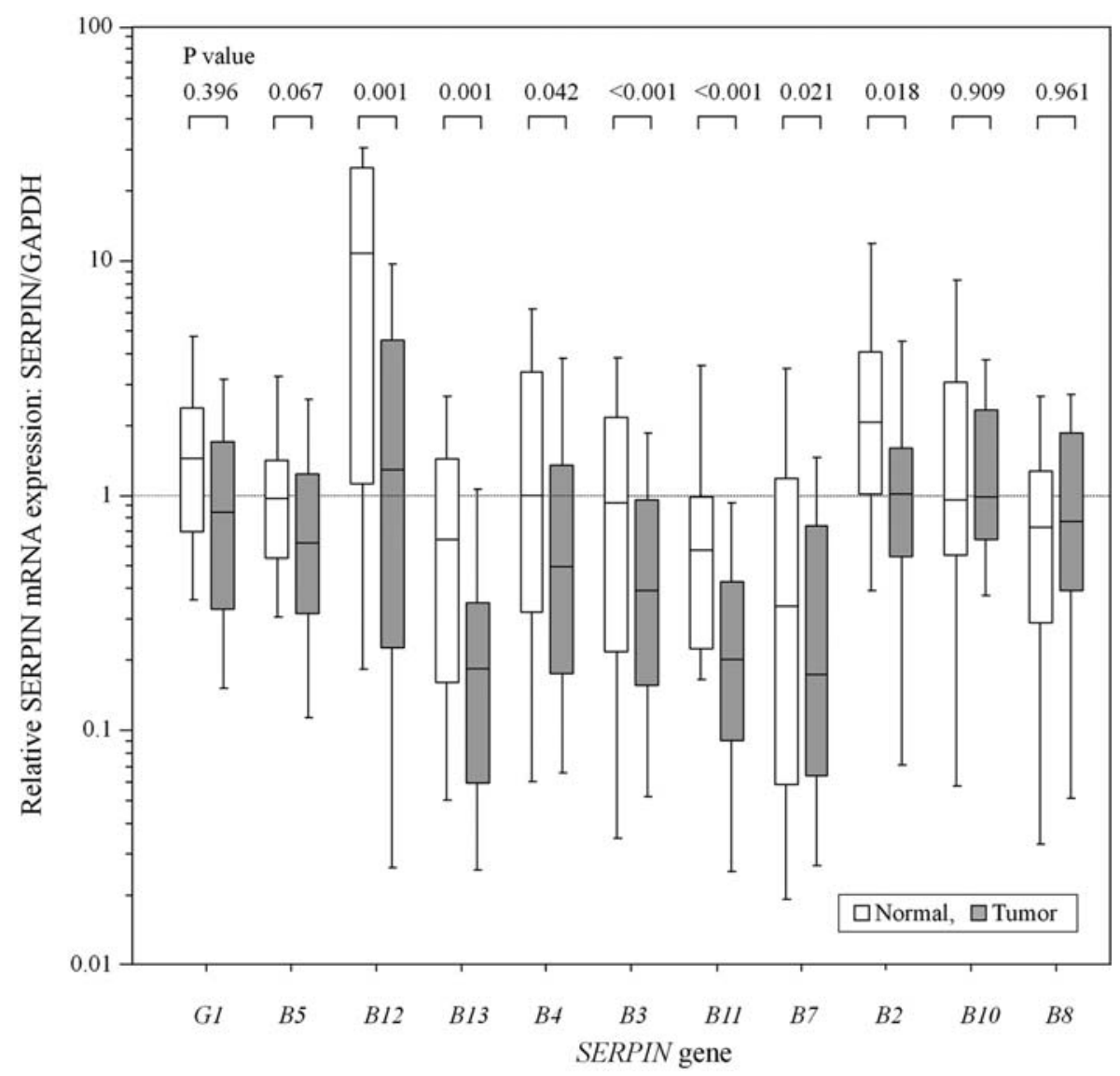

Figure 1. Comparison of mRNA expressions of SERPIN genes in primary OSCC samples and normal oral epithelial tissues. Statistically significant downregulation of SERPINB12, SERPINB13, SERPINB4, SERPINB3, SERPINB11, SERPINB7 and SERPINB2 was observed in OSCC samples when compared with normal tissues.

checked with the Primer3 program (available at http:wwwgenome.wi.mi.edu/cgi-bin/primer/primer3_www.cgi), to avoid amplification of genomic DNA or pseudogenes. The qRT-PCR analysis was performed using the LightCycler FastStart DNA Master SYBR Green I kit (Roche, Mannheim, Germany). Details are described in our previous report (22). The transcript amount for each of the 11 genes of the serpin superfamily was estimated from the respective standard curves and normalized to the GAPDH transcript amount determined in corresponding samples using primers specific for the GAPDH genes (sense, 5'-CATCTCTGCCCCCTCTG CTGA-3'; antisense, 5'-GGATGACCTTGCCACAGCCT-3'). Amplified products were analyzed by agarose gel electrophoresis to ascertain size and purity.

Network analysis and canonical pathway analysis. Gene accession numbers and the results of global gene screening using microarray analysis were imported into IPA software (Ingenuity Systems, Redwood City, CA, USA). This software categorized the genes based on location, cellular components, and reported or suggested biochemical, biologic and molecular functions. The identified genes were also mapped to genetic networks available in the Ingenuity database (Ingenuity Systems) and then ranked by score, which reflected the probability that a collection of genes equal to or greater than the number in a network could be achieved by chance alone. A score of 3 indicated a 1/1000 chance that the focus genes were in a network because of chance. Therefore, scores $\geq 3$ had a $99.9 \%$ confidence level of not being generated by chance alone.

Statistical analysis. Differences of the mRNA expression levels of SERPIN genes between normal tissues and OSCC samples were analyzed using paired t-tests and correlations between mRNA expression levels of SERPIN genes and clinicopathologic features were analyzed using the Fisher's exact test. Disease-free rate was defined as the percentage of patients for a given time interval between tumor treatment and detection of the first locoregional recurrence, distant metastasis or both, or the date of last follow-up, whichever occurred first. Disease-free rate was analyzed using the Kaplan-Meier analysis and differences in disease-free rates between groups with high or low expression of SERPINB11 were compared using the log-rank test. P-values $<0.05$ were taken to indicate statistical significance.

\section{Results}

SERPIN gene expressions in OSCC-derived cell lines using microarray analysis. Global gene screening of OSCC cell lines was carried out with DNA microarray analysis. Expressions of SERPIN genes in OSCC cell lines compared with normal controls are summarized in Table III. Gene expression was down-regulated in 3 or more OSCC cell lines for 


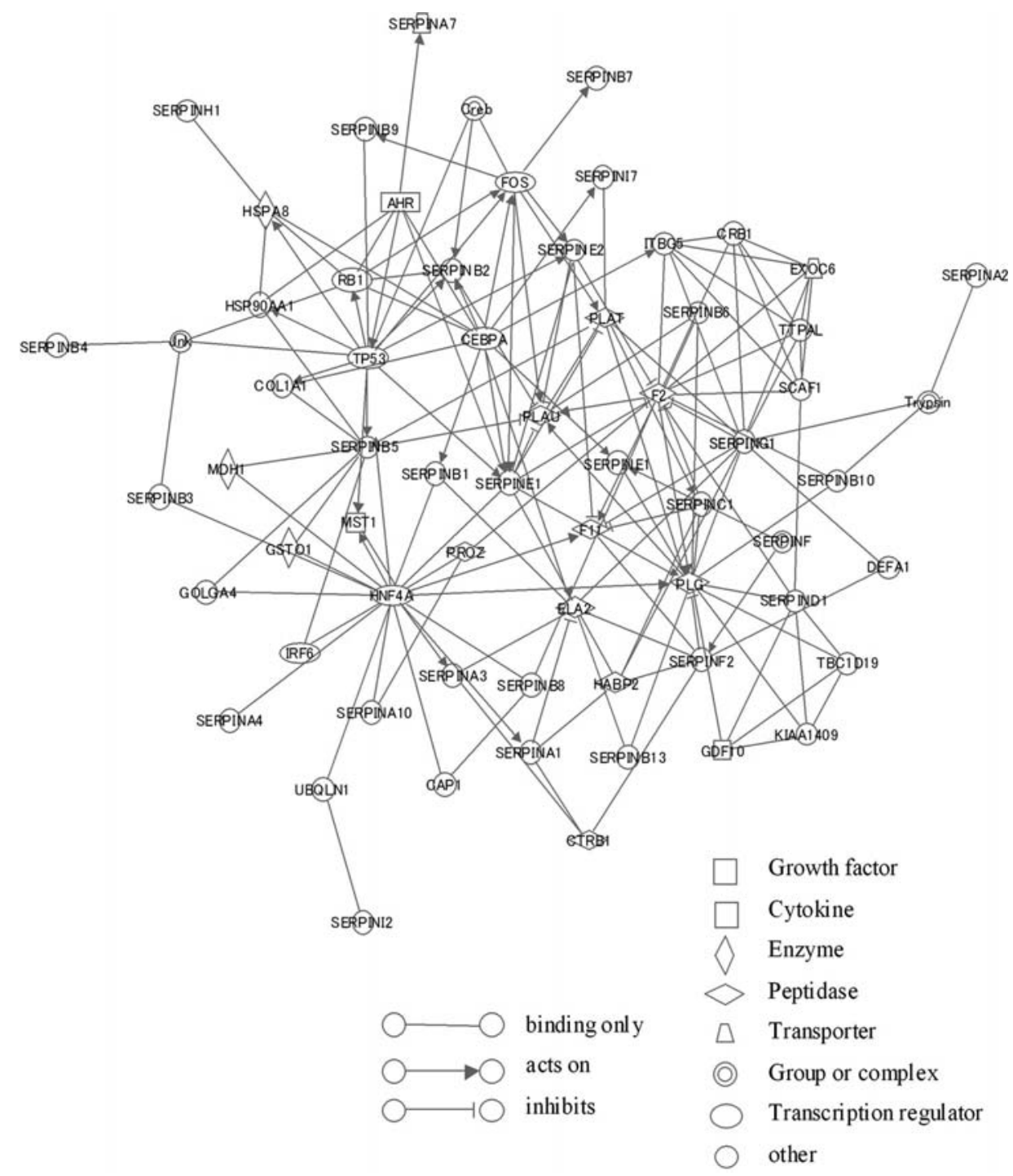

Figure 2. Network of molecules related to serpin family members identified by IPA software. Gene accession numbers and the results of global gene screening using microarray analysis were imported into the IPA software. The identified network shows the classification of molecules and their interactions.

SERPING1, SERPINB5, SERPINB7 and SERPINB2. Of these genes, SERPINB5, SERPINB7 and SERPINB2 are known to be located on $18 \mathrm{q} 21.3$, thus, the data strongly suggested that this chromosomal region is crucial for the development of OSCC. We therefore performed further examinations to validate the expression profiles of SERPIN genes located on 18q21.3.

mRNA expression of SERPIN genes in OSCC samples. To confirm the expression profiles of SERPIN genes, mRNA expression levels were determined by qRT-PCR analyses in 55 OSCC samples obtained from patients with primary OSCC. Compared with matched normal tissues, mRNA expression levels of SERPINB12 ( $\mathrm{P}=0.001)$, SERPINB13 ( $\mathrm{P}=0.001)$, SERPINB4 $(\mathrm{P}=0.042)$, SERPINB3 $(\mathrm{P}<0.001)$, SERPINB11 $(\mathrm{P}<0.001)$, SERPINB7 $(\mathrm{P}=0.021)$ and SERPINB2 $(\mathrm{P}=0.018)$ were significantly decreased in OSCC samples (Fig. 1).

Genetic network analysis and canonical pathway analysis for the serpin family. Genetic network analysis including SERPIN family members was performed using IPA software. The analysis suggested that there were two networks of molecules related to the serpin family (Table V), and the biological interactions between these molecules are summarized in Fig. 2. The figure shows binding of SERPINB3 or SERPINB4 with jnk, which is a member of the MAP kinase family and involved in a wide variety of cellular processes such as proliferation, differentiation, transcription regulation and development. In addition FOS, which can form the transcription factor complex AP-1 and can regulate cell proliferation, differentiation and transformation, acted on SERPINB7 and SERPINB9. TP53 acted on SERPINB5 and SERPINB2. $\mathrm{RB} 1$, a tumor suppressor, is also included in the network. The data suggest that members of the serpin family might have a close relationship with some of the tumor-related molecules. SERPINB11 and SERPINB12 are not shown in the network because few reports have so far been published on these molecules.

Relationship between clinical factors and SERPIN gene expression. The relationship between clinical factors and mRNA expression of serpin family members was assessed. 
Table IV. Correlation between mRNA expressions of SERPIN genes and clinical classification.

A. T classification

\begin{tabular}{|c|c|c|c|c|}
\hline \multirow[b]{2}{*}{ Gene } & \multirow[b]{2}{*}{ Tumor size } & \multicolumn{2}{|c|}{ No. of cases } & \multirow[b]{2}{*}{ P-value } \\
\hline & & Highly expressive, $\mathrm{T} / \mathrm{N}$ ratio $>1(\%)$ & Lower expressive, $\mathrm{T} / \mathrm{N}$ ratio $<1(\%)$ & \\
\hline \multirow[t]{2}{*}{ SERPINB12 } & $\mathrm{T} 1$ or $\mathrm{T} 2$ & $7(26)$ & $20(74)$ & $>0.999$ \\
\hline & $\mathrm{T} 3$ or $\mathrm{T} 4$ & $7(25)$ & $21(75)$ & \\
\hline \multirow[t]{2}{*}{ SERPINB13 } & $\mathrm{T} 1$ or $\mathrm{T} 2$ & $7(26)$ & $20(74)$ & $>0.999$ \\
\hline & $\mathrm{T} 3$ or $\mathrm{T} 4$ & $8(29)$ & $20(71)$ & \\
\hline \multirow[t]{2}{*}{ SERPINB4 } & $\mathrm{T} 1$ or $\mathrm{T} 2$ & $12(44)$ & $15(56)$ & 0.2695 \\
\hline & $\mathrm{T} 3$ or $\mathrm{T} 4$ & $8(29)$ & $20(71)$ & \\
\hline \multirow[t]{2}{*}{ SERPINB3 } & $\mathrm{T} 1$ or $\mathrm{T} 2$ & $12(44)$ & $15(56)$ & 0.2695 \\
\hline & $\mathrm{T} 3$ or $\mathrm{T} 4$ & $8(29)$ & $20(71)$ & \\
\hline \multirow[t]{2}{*}{ SERPINBI1 } & $\mathrm{T} 1$ or $\mathrm{T} 2$ & $7(26)$ & $20(74)$ & $>0.999$ \\
\hline & $\mathrm{T} 3$ or $\mathrm{T} 4$ & $7(25)$ & $21(75)$ & \\
\hline \multirow[t]{2}{*}{ SERPINB7 } & $\mathrm{T} 1$ or $\mathrm{T} 2$ & $7(26)$ & $20(74)$ & 0.1625 \\
\hline & $\mathrm{T} 3$ or $\mathrm{T} 4$ & $13(46)$ & $15(54)$ & \\
\hline \multirow[t]{2}{*}{ SERPINB2 } & $\mathrm{T} 1$ or $\mathrm{T} 2$ & 7 (26) & $20(74)$ & 0.1625 \\
\hline & $\mathrm{T} 3$ or $\mathrm{T} 4$ & $13(46)$ & $15(54)$ & \\
\hline
\end{tabular}

aP-values were calculated with Fisher's exact analysis.

B. $\mathrm{N}$ classification.

\begin{tabular}{|c|c|c|c|c|}
\hline \multirow[b]{2}{*}{ Gene } & \multirow{2}{*}{$\begin{array}{l}\text { Regional neck } \\
\text { metastasis }\end{array}$} & \multicolumn{2}{|c|}{ No. of cases } & \multirow[b]{2}{*}{ P-value } \\
\hline & & Highly expressive, $\mathrm{T} / \mathrm{N}$ ratio $>1(\%)$ & Lower expressive, $\mathrm{T} / \mathrm{N}$ ratio $<1(\%)$ & \\
\hline \multirow[t]{2}{*}{ SERPINB12 } & $\mathrm{N}(-)$ & 3 (18) & $14(82)$ & 0.3440 \\
\hline & $\mathrm{N}(+)$ & $12(32)$ & $26(68)$ & \\
\hline \multirow[t]{2}{*}{ SERPINB13 } & N (-) & $4(24)$ & $13(76)$ & 0.7542 \\
\hline & $\mathrm{N}(+)$ & $11(29)$ & $27(71)$ & \\
\hline \multirow[t]{2}{*}{ SERPINB4 } & $\mathrm{N}(-)$ & $8(47)$ & $9(53)$ & 0.2290 \\
\hline & $\mathrm{N}(+)$ & $11(29)$ & $27(71)$ & \\
\hline \multirow[t]{2}{*}{ SERPINB3 } & N (-) & $9(53)$ & $8(47)$ & 0.1478 \\
\hline & $\mathrm{N}(+)$ & $12(32)$ & $26(68)$ & \\
\hline \multirow[t]{2}{*}{ SERPINBI1 } & $\mathrm{N}(-)$ & $2(12)$ & $15(88)$ & 0.3026 \\
\hline & $\mathrm{N}(+)$ & $12(31)$ & $27(69)$ & \\
\hline \multirow[t]{2}{*}{ SERPINB7 } & N (-) & $5(30)$ & $12(70)$ & 0.5491 \\
\hline & $\mathrm{N}(+)$ & $16(42)$ & $22(58)$ & \\
\hline \multirow[t]{2}{*}{ SERPINB2 } & N (-) & $5(29)$ & $12(71)$ & 0.5545 \\
\hline & $\mathrm{N}(+)$ & $15(40)$ & $23(60)$ & \\
\hline
\end{tabular}

ap-values were calculated with Fisher's exact analysis. 
Table IV. Continued.

C. Differentiation.

\begin{tabular}{|c|c|c|c|c|}
\hline \multirow[b]{2}{*}{ Gene } & \multirow[b]{2}{*}{ Differentiation } & \multicolumn{2}{|c|}{ No. of cases } & \multirow[b]{2}{*}{ P-value ${ }^{a}$} \\
\hline & & Highly expressive, $\mathrm{T} / \mathrm{N}$ ratio $>1(\%)$ & Lower expressive, $\mathrm{T} / \mathrm{N}$ ratio $<1(\%)$ & \\
\hline \multirow[t]{2}{*}{ SERPINB12 } & Well & $10(32)$ & $21(68)$ & 0.3800 \\
\hline & Moderate or Poor & $5(21)$ & $19(79)$ & \\
\hline \multirow[t]{2}{*}{ SERPINB 13} & Well & $9(29)$ & $22(71)$ & 0.7706 \\
\hline & Moderate or Poor & $6(25)$ & $18(75)$ & \\
\hline \multirow[t]{2}{*}{ SERPINB4 } & Well & $12(39)$ & $19(61)$ & 0.7808 \\
\hline & Moderate or Poor & $8(33)$ & $16(67)$ & \\
\hline \multirow[t]{2}{*}{ SERPINB3 } & Well & $13(42)$ & $18(58)$ & 0.1480 \\
\hline & Moderate or Poor & $5(21)$ & $19(79)$ & \\
\hline \multirow[t]{2}{*}{ SERPINBII } & Well & $12(39)$ & $19(61)$ & 0.0371 \\
\hline & Moderate or Poor & $3(13)$ & $21(87)$ & \\
\hline \multirow[t]{2}{*}{ SERPINB7 } & Well & $13(42)$ & $18(58)$ & 0.5835 \\
\hline & Moderate or Poor & $8(33)$ & $16(67)$ & \\
\hline \multirow[t]{2}{*}{ SERPINB2 } & Well & $14(45)$ & $17(55)$ & 0.2718 \\
\hline & Moderate or Poor & $7(29)$ & $17(71)$ & \\
\hline
\end{tabular}

aP-values were calculated with Fisher's exact analysis.

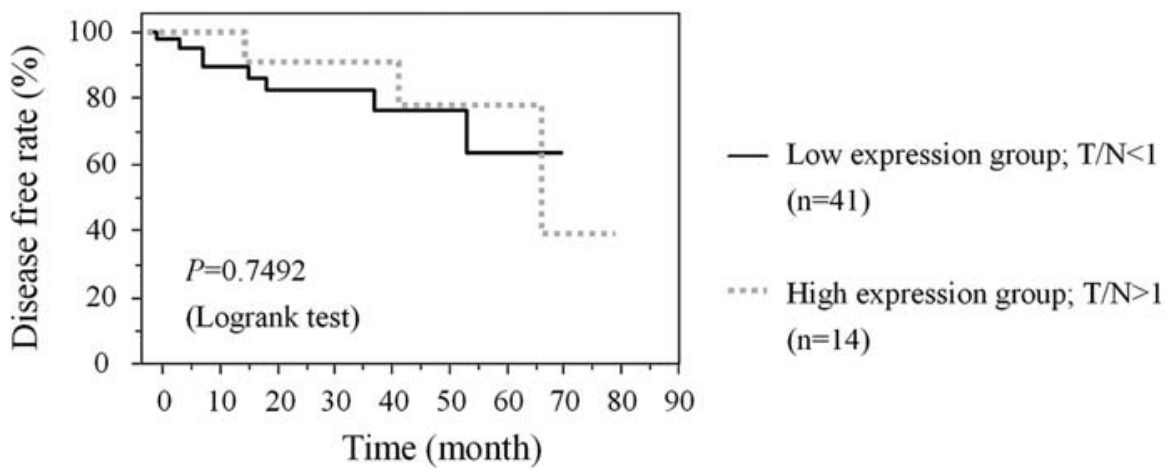

Figure 3. Comparison of disease-free rates with respect to SERPINB11 mRNA expression status in OSCC. The overall disease-free rates in relation to the level of SERPINB11 gene expression were determined by Kaplan-Meier analysis. OSCC cases were divided into high expression (T/N ratio >1.0) and lower expression $(\mathrm{T} / \mathrm{N}$ ratio <1.0) groups. Disease-free rates tended to be decreased in the lower expression group; however, no statistically significant difference was observed.

There was no significant association between the $\mathrm{T} / \mathrm{N}$ ratio of SERPIN gene expression and the $\mathrm{T}$ classification or $\mathrm{N}$ classification or other clinicodemographic characteristics (Table IVA and B). However, T/N ratios of gene expression in SERPIN genes that were down-regulated in tumor tissues tended to decrease in moderate or poorly differentiated tumors compared with well-differentiated tumors (Table IVC). In particular, significantly diminished mRNA expression was found for SERPINB11 ( $\mathrm{P}=0.0371)$. Disease-free rate was estimated by Kaplan-Meier analysis and compared with SERPINB11 expression in OSCC cases. Cases were divided into high expression $(\mathrm{T} / \mathrm{N}$ ratio $>1.0)$ and lower expression ( $\mathrm{T} / \mathrm{N}$ ratio $<1.0)$ groups, and disease-free rates were compared. Disease-free rates in the lower expression group tended to be decreased, although no statistically significant difference was observed (Fig. 3).

\section{Discussion}

Previous studies have demonstrated that SERPINB5 and SERPINB13 have crucial roles as tumor suppressor genes; it is therefore reasonable to speculate that other serpin members 
Table V. Networks of molecules related to the serpin family.

\begin{tabular}{|c|c|c|c|c|}
\hline Network & Molecules in Network & Score & $\begin{array}{c}\text { Focus } \\
\text { molecules }\end{array}$ & Top functions \\
\hline 1 & $\begin{array}{l}\text { AHR, CAP1, CEBPA, COL1A2, Creb, CTRB1, FOS, } \\
\text { GOLGA4, GSTO1, HNF4A, HSP90AA1, IRF6, Jnk, } \\
\text { MDH1, MST1, PLAT, PLAU, PROZ, RB1, SERPINA1, } \\
\text { SERPINA3, SERPINA4, SERPINA7, SERPINA10, } \\
\text { SERPINB3, SERPINB4, SERPINB5, SERPINB7, } \\
\text { SERPINB8, SERPINB9, SERPINE1, SERPINE2, } \\
\text { SERPINI2, TP53, UBQLN1 }\end{array}$ & 33 & 14 & $\begin{array}{l}\text { Cardiovascular disease, } \\
\text { hematological disease, } \\
\text { organismal injury } \\
\text { and abnormalities }\end{array}$ \\
\hline 2 & $\begin{array}{l}\text { CEBPA, CRB1, DEFA1 (includes EG:1667), ELA2, } \\
\text { EXOC6, F2, F11, GDF10, HABP2, HSPA8, ITGB5, } \\
\text { KIAA1409, PLAT, PLAU, PLG, RB1, SCAF1, } \\
\text { SERPINA2, SERPINB1, SERPINB2, SERPINB6, } \\
\text { SERPINB10, SERPINB13, SERPINC1, SERPIND1, } \\
\text { SERPINF, SERPINF1, SERPINF2, SERPING1, } \\
\text { SERPINH1, SERPINI1, TBC1D19, Trypsin, TTPAL }\end{array}$ & 30 & 13 & $\begin{array}{l}\text { Cardiac pulmonary embolism, } \\
\text { cardiovascular disease, } \\
\text { respiratory disease }\end{array}$ \\
\hline
\end{tabular}

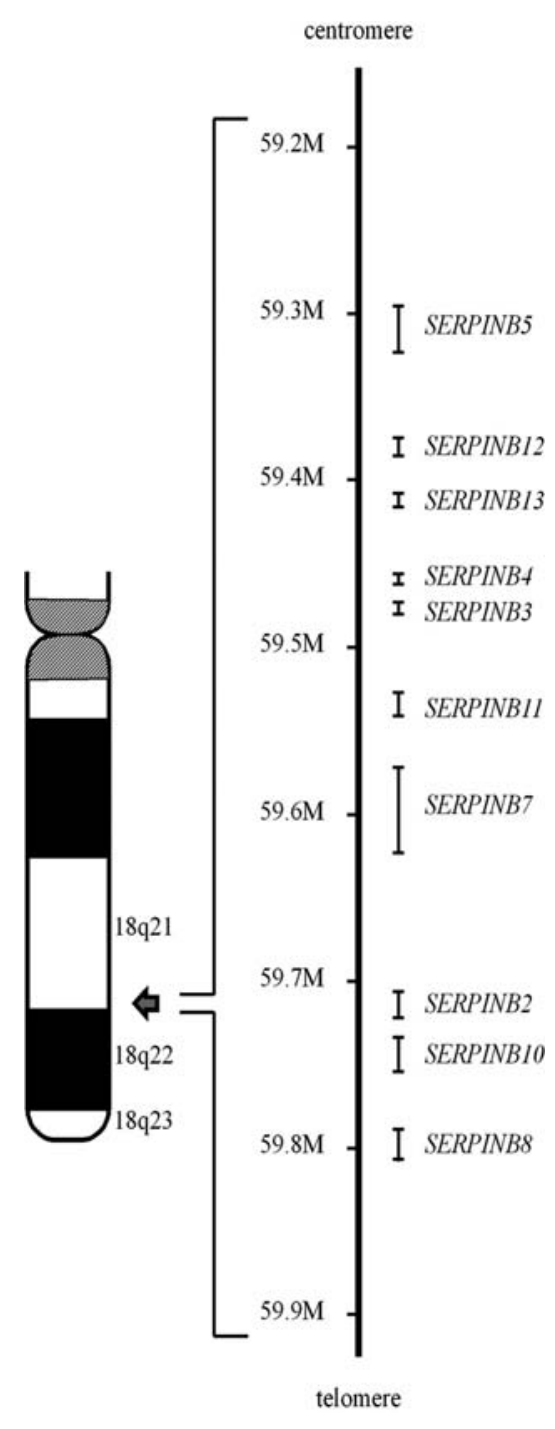

Figure 4. Schema of chromosome 18. The figure shows the location of the SERPIN gene cluster in chromosome region $18 \mathrm{q} 21$. that have conserved conformations might possess similar activities in oral carcinomas. Therefore, in the present study, overall gene expression profiling was performed by DNA microarray analysis. This revealed that down-regulation of SERPIN genes was frequently observed in chromosome 11q12-q13.1 and 18q21.3. Real-time qRT-PCR analysis was then performed to validate the expression profiles of serpin members located at these chromosome regions in OSCC samples (see also Fig. 4).

Statistically significant down-regulations of mRNA expression were found for SERPINB12 (18q21.3), SERPINB13 (18q21.3-q22), SERPINB4 (18q21.3), SERPINB3 (18q21.3), SERPINB11 (18q21.3), SERPINB7 (18q21.33) and SERPINB2 (18q21.3). Interestingly, these serpins belong to the clade B serpin group, suggesting that their conserved common characteristics should be closely associated with tumorigenesis in oral carcinoma. Unlike the majority of serpin members that exist in the serum and are involved in blood coagulation, fibrinolysis and inflammation, clade B serpins have predominantly intracellular functions. The present pathway analysis revealed that clade $\mathrm{B}$ serpins are closely related to various molecules including cancer-related molecules. Thus, the data suggest that clade B serpin members play crucial roles in tumor suppression through mechanisms such as signal transduction pathways for cell proliferation or differentiation.

Serpin members were originally identified as protease inhibitors; however, our data strongly suggest that serpin members other than SERPINB5 or SERPINB13 have tumor suppressive activities. Recently, De Koning et al demonstrated that down-regulation of SERPINB13 expression was positively associated with poor clinical outcome in human head and neck squamous cell carcinomas, and that SERPINB13 may act as an important protease inhibitor involved in the progression of head and neck squamous cell carcinomas (23). In the present study, mRNA expression of SERPINB11 was significantly diminished in poorly or moderately differentiated 
OSCC cases when compared with well-differentiated cases. There was also a trend toward worse outcome in the group with lower expression of SERPINB 11. This suggests that SERPINB11 is extremely important in the clinical setting and might have potential as a biomarker of OSCC.

Askew et al reported that single nucleotide polymorphisms in the scaffold induce conformational changes of SERPINB11, which result in the loss of trypsin inhibitory activity (24). SERPINB11 has not yet been reported as a tumor suppressor, but our data suggest that it could potentially possess the tumor suppressive function and may be particularly associated with cell differentiation. The present data revealed that downregulated expression was frequently observed for serpin members located at $18 \mathrm{q} 21$, suggesting that this chromosome region is crucial in oral carcinomas.

Region $18 \mathrm{q} 21$ is one of the well-known instable chromosome regions in oral carcinomas, at which genetic alterations such as $\mathrm{LOH}$ or microsatellite instability have been frequently reported, indicating that there may be unidentified tumor suppressor gene in this region $(16,18,20,25)$. Previously, we found a high frequency of LOH (43.8\%) at 18q21 in OSCCs. In contrast, $D C C$ (deleted in colorectal carcinoma) and DPC4 (deleted in pancreatic carcinoma 4) gene, both located at 18q21, were not detected (21). These findings and our present data strongly suggest that further investigations are essential to clarify whether members of the serpin family located at $18 \mathrm{q} 21$ have tumor suppressive activities in oral carcinomas.

In conclusion, the present data revealed that mRNA expressions of clade B SERPINs clustering at $18 \mathrm{q} 21$ are significantly down-regulated in OSCC. In particular, SERPINB11 mRNA expression was associated with the level of differentiation, suggesting that it might be important in this aspect. Although tumor suppressive activity has not been indicated for these serpins with the exception of SERPINB5 and SERPINB13 in OSCC, other serpins might function as tumor suppressors. Furthermore, there might be additional unidentified tumor suppressor genes in this chromosome region.

\section{Acknowledgements}

This study was partly supported by the Global COE Program (Global Center for Education and Research in Immune System Regulation and Treatment), Ministry of Education, Culture, Sports, Science and Technology of Japan.

\section{References}

1. Potempa J, Korzus E and Travis J: The serpin superfamily of proteinase inhibitors: structure, function and regulation. J Biol Chem 269: 15957-15960, 1994

2. Law RH, Zhang Q, McGowan S, et al: An overview of the serpin superfamily. Genome Biol 7: 216, 2006.

3. Nagata K: Hsp47: a collagen-specific molecular chaperone. Trends Biochem Sci 21: 22-26, 1996.

4. Pemberton PA, Stein PE, Pepys MB, Potter JM and Carrell RW: Hormone binding globulins undergo serpin conformational change in inflammation. Nature 336: 257-258, 1988.

5. Silverman GA, Bird PI, Carrell RW, et al: The serpins are an expanding superfamily of structurally similar but functionally diverse proteins. Evolution, mechanism of inhibition, novel functions and a revised nomenclature. J Biol Chem 276: 33293-33296, 2001.
6. Zou Z, Anisowicz A, Hendrix MJ, et al: Maspin, a serpin with tumor-suppressing activity in human mammary epithelial cells. Science 263: 526-529, 1994.

7. Machtens S, Serth J, Bokemeyer C, et al: Expression of the p53 and Maspin protein in primary prostate cancer: correlation with clinical features. Int J Cancer 95: 337-342, 2001.

8. Ohike N, Maass N, Mundhenke C, et al: Clinicopathological significance and molecular regulation of maspin expression in ductal adenocarcinoma of the pancreas. Cancer Lett 199: 193-200, 2003.

9. Sood AK, Fletcher MS, Gruman LM, et al: The paradoxical expression of maspin in ovarian carcinoma. Clin Cancer Res 8: 2924-2932, 2002.

10. Yu M, Zheng H, Tsuneyama K, et al: Paradoxical expression of maspin in gastric carcinomas: correlation with carcinogenesis and progression. Hum Pathol 38: 1248-1255, 2007.

11. Xia W, Lau YK, Hu MC, et al: High tumoral maspin expression is associated with improved survival of patients with oral squamous cell carcinoma. Oncogene 19: 2398-2403, 2000.

12. Nakashima T, Pak SC, Silverman GA, Spring PM, Frederick MJ and Clayman GL: Genomic cloning, mapping, structure and promoter analysis of HEADPIN, a serpin which is downregulated in head and neck cancer cells. Biochim Biophys Acta 1492: 441-446, 2000.

13. Shellenberger TD, Mazumdar A, Henderson Y, et al: Headpin: a serpin with endogenous and exogenous suppression of angiogenesis. Cancer Res 65: 11501-11509, 2005.

14. Spring P, Nakashima T, Frederick M, Henderson Y and Clayman G: Identification and cDNA cloning of headpin, a novel differentially expressed serpin that maps to chromosome 18q. Biochem Biophys Res Commun 264: 299-304, 1999.

15. Frank CJ, McClatchey KD, Devaney KO and Carey TE: Evidence that loss of chromosome $18 \mathrm{q}$ is associated with tumor progression. Cancer Res 57: 824-827, 1997.

16. Jones JW, Raval JR, Beals TF, et al: Frequent loss of heterozygosity on chromosome arm $18 \mathrm{q}$ in squamous cell carcinomas. Identification of 2 regions of loss-18q11.1-q12.3 and 18q21.1-q23. Arch Otolaryngol Head Neck Surg 123: 610-614, 1997.

17. Pearlstein RP, Benninger MS, Carey TE, et al: Loss of $18 \mathrm{q}$ predicts poor survival of patients with squamous cell carcinoma of the head and neck. Genes Chromosomes Cancer 21: 333-339, 1998.

18. Scully C, Field JK and Tanzawa H: Genetic aberrations in oral or head and neck squamous cell carcinoma 2: chromosomal aberrations. Oral Oncol 36: 311-327, 2000.

19. Scully C, Field JK and Tanzawa H: Genetic aberrations in oral or head and neck squamous cell carcinoma 3: clinicopathological applications. Oral Oncol 36: 404-413, 2000.

20. Takebayashi S, Hickson A, Ogawa T, et al: Loss of chromosome arm $18 \mathrm{q}$ with tumor progression in head and neck squamous cancer. Genes Chromosomes Cancer 41: 145-154, 2004.

21. Watanabe T, Wang X, Miyakawa A, et al: Mutational state of tumor suppressor genes (DCC, DPC4) and alteration on chromosome 18q21 in human oral cancer. Int J Oncol 11: 1287-1290, 1997.

22. Ishigami $\mathrm{T}$, Uzawa $\mathrm{K}$, Higo $\mathrm{M}$, et al: Genes and molecular pathways related to radioresistance of oral squamous cell carcinoma cells. Int J Cancer 120: 2262-2270, 2007.

23. De Koning PJA, Bovenschen N, Leusink FKJ, et al: Downregulation of SERPINB13 expression in head and neck squamous cell carcinomas associated with poor clinical outcome. Int $\mathrm{J}$ Cancer 125: 1542-1550, 2009.

24. Askew DJ, Cataltepe S, Kumar V, et al: SERPINB11 is a new non-inhibitory intracellular serpin. Common single nucleotide polymorphisms in the scaffold impair conformational change. $\mathrm{J}$ Biol Chem 282: 24948-24960, 2007.

25. Rowley H, Jones AS and Field JK: Chromosome 18: a possible site for a tumour suppressor gene deletion in squamous cell carcinoma of the head and neck. Clin Otolaryngol Allied Sci 20: 266-271, 1995. 